\title{
Bioactive compounds and antioxidant activity in the common bean are influenced by cropping season and genotype
}

\author{
Yatzil Denih García-Díaz ${ }^{1}$, Elia Nora Aquino-Bolaños², José Luis Chávez-Servia ${ }^{*}$, \\ Araceli Minerva Vera-Guzmán ${ }^{1}$, and José Cruz Carrillo-Rodrīguez ${ }^{3}$ \\ ${ }^{1}$ Instituto Politécnico Nacional, CIIDIR-Oaxaca, 71230 Santa Cruz Xoxocotlán, Oaxaca, México. \\ *Corresponding author (jchavezs@ipn.mx). \\ ${ }^{2}$ Universidad Veracruzana, Instituto de Ciencias Básicas, Av. Doctor Luis Castelazo, Industrial Las Ánimas, 91190 Xalapa, \\ Veracruz, México. \\ ${ }^{3}$ Instituto Tecnológico del Valle de Oaxaca, 71230 Ex-hacienda Nazareno, Santa Cruz Xoxocotlán, Oaxaca, México.
}

Received: 4 January 2018; Accepted: 25 April 2018; doi:10.4067/S0718-58392018000200255

\begin{abstract}
The Mesoamerican region is a center of domestication and high genetic diversity of Phaseolus vulgaris L., which continues to evolve on-farm as part of multi-cropping systems (milpa) and is commonly associated with maize. The genetic resources of the common bean provide knowledge of its agronomic potential. However, there is also a need to document the biochemical composition of the seed in the genetic resources preserved by Mesoamerican farmers. To assess the genotypic and environmental effects on the polyphenol, flavonoid and monomeric anthocyanin contents, and antioxidant activity (DPPH) in seed coats and cotyledons of the common bean, 54 native populations and five improved varieties were evaluated from seed samples that were cultivated in two cropping seasons under a randomized complete block design with four replicates. In addition, seed color parameters were evaluated. At harvest time, a dry sample of grain was obtained from each population, and after a soaking treatment of $12 \mathrm{~h}$, seed coats were separated from cotyledons. The evaluated populations and varieties of common beans showed significant differences $(\mathrm{P}<0.05)$ in polyphenol, flavonoid and anthocyanin compositions, antioxidant activity, and seed color parameters. The geographical origins of the populations and cropping season significantly affected the compositions of the seed coats and cotyledons, and the regions of origin and populations had significant interactions with the cropping season. Among populations, phenolic compound concentrations and antioxidant activities were higher in dark or pigmented seed coats than in the cotyledons. The genotype-environment interaction effects in bioactive compounds provide insights into options for genetic improvement of the common bean to promote their consumption.
\end{abstract}

Key words: Bioactive compounds, chemical variation, common bean landraces, genotype-environment interactions, Phaseolus vulgaris, phenotypic diversity.

\section{INTRODUCTION}

The common bean (Phaseolus vulgaris L.) is the most commonly eaten legume. This crop has been cultivated for hundreds of years and plays an important role in the traditional diets of various regions of America, Africa and Asia, with different levels of consumption ranging from $110 \mathrm{~g}$ up to $10.38 \mathrm{~kg}$ per person per year (FAOSTAT, 2015). In Latin America, the common bean is the main grain consumed by families (Moreno-Jiménez et al., 2014). Bean consumption remains high despite several changes in dietary patterns as a consequence of homogenization of diets, access problems, 
food preparation times and cultural changes, among other factors. The largest productions worldwide come from India, Brazil, Myanmar, Mexico, Tanzania, Kenya, China, Angola, USA, and Uganda (FAOSTAT, 2015).

Bean grains are a source of carbohydrates, proteins, lipids, vitamin B, fiber, minerals, and bioactive compounds with high antioxidant activity, such as flavonoids, anthocyanins, polyphenols, tannins and flavones, among others. These functional compounds have been associated with the prevention of chronic degenerative diseases, including diabetes, obesity, cardiovascular diseases and colon, breast, intestinal and ovarian cancer, through their antimutagenic, vasodilatory, anti-inflammatory and anticancer activities (Camacho et al., 2007; Oomah et al., 2010; Ezeagu and Ibegbu, 2010; Xu and Chang, 2012; García-Lafuente et al., 2014; Moreno-Jiménez et al., 2014; Romano et al., 2015; Sancho et al., 2015).

The polyphenols in bean seeds confer nutraceutical properties that are associated with free radical scavenging, metal chelating, and antioxidant activities (Rocha-Guzmán et al., 2007; Oomah et al., 2010; Romero-Arenas et al., 2013; GarcíaLafuente et al., 2014; Mojica et al., 2015). The total polyphenols content reported in beans is higher than the content in lentils, chickpeas and soybeans (Marathe et al., 2011; García-Lafuente et al., 2014), which is related to higher antioxidant activity (Xu and Chang, 2012). However, the samples used in several studies that tested the polyphenol, flavonoid, and anthocyanin contents in beans have been mostly confined to improved varieties, whereas few studies included wild species or landraces of cultivated variants (Romani et al., 2004; Espinosa-Alonso et al., 2006). The evolution of landraces through domestication by small-scale farmers continues by inducing changes in the seed composition through selection over time and space (Bitocchi et al., 2013). However, these selection events and adaptation to local agroecological niches have been poorly documented, although they are linked to the nutritional-nutraceutical differences between common bean landraces that are the food base of a high number of families.

The seed coat color of beans is frequently highly variable. This trait is determined by nine major epistatic genes that are responsible for generating changes in the patterns of seed color variation ranging from homogeneous primary colors, secondary colors expressed as spots, marks, stripes or variegated patterns or a combination of two phenotypic expressions until uniform color (McClean et al., 2002; Possobom et al., 2015).

Several compounds are concentrated in the bean seed coats; these confer beneficial effects for human health when consumed (e.g., a reduction of the cholesterol level) (Chavez-Santoscoy et al., 2014). Mojica et al. (2015) reported the effects of anthocyanins on $\alpha$-amylase and $\alpha$-glucosidase, which intervene in the digestion of sugars and consequently inhibits the development of type 2 diabetes. A similar response was reported by Lomas-Soria et al. (2015), who observed a decrease in glucose levels of up to $25 \%$. However, improved varieties were evaluated in all reports, and little is known about the gene pools that are native to the origin centers of the species or landraces preserved by small-scale farmers. There is evidence that landraces undergo greater agroecological adaptation to microniches and have a higher cooking quality, stronger consumer preference and some resistance to diseases or abiotic stresses (Zhang et al., 2008).

Bean seed composition depends on different factors, including genetics (species, variety or type of primary or secondary gene pool), agroecological conditions of the growing site, agricultural practices during cultivation and post-harvest management related to the drying, temperature and storage times (Prolla et al., 2010). Mexico is the center of origin of the common bean and has an extensive diversity of wild populations, landraces and improved varieties (Voysest, 2000). Additionally, high genetic variation and environmental effects on the phenolic and micronutrient contents in cultivated and wild beans have been reported (Barampama and Simard, 1993; Muzquiz et al., 1999).

In this context, the phenolic compound, flavonoid and anthocyanin contents and the antioxidant activity in the seed coats and cotyledons were evaluated in a collection of common bean populations from Oaxaca, Mexico. The bean collection was grown in two different cropping seasons, one per year. The study aimed to provide information for the formulation of conservation and local utilization strategies to satisfy the daily nutritional needs of families and initiate a participatory program of genetic improvement with communitarian objectives.

\section{MATERIALS AND METHODS}

\section{Common bean origin and multiplication}

In the first phase, seed lots were collected from 54 native bean populations from four regions of Oaxaca, Mexico. Then, the collection and five improved varieties ('Peruano', 'Pinto', 'Flor de Mayo', 'Black Horse' and 'Negro Tropical') were planted and cultivated under a randomized complete block design in San Agustin Amatengo, Oaxaca (16³0'37' 
N, 96 47’21” W; $1361 \mathrm{~m}$ a.s.1.), for two cropping seasons from May to December in 2014 and 2015. A combined seed sample of approximately $500 \mathrm{~g}$ for each evaluated population and controls were obtained at harvest and stored at $-20{ }^{\circ} \mathrm{C}$ in darkness prior to laboratory analysis. For each population, the seed coat color was measured with a spectrophotometer (Konica Minolta, CM-2600d, Osaka, Japan) using the $\mathrm{L}^{*}$, $\mathrm{a}^{*}$ and $\mathrm{b}^{*}$ parameters; and the chroma $C^{*}=\left(a^{* 2}+b^{* 2}\right)^{1 / 2}$ and hue angle $\mathrm{h}^{\circ}=\tan ^{-1}\left(b^{*} / a^{*}\right)$ indexes were calculated according to McGuire (1992).

\section{Preparation of sample extracts}

For each seed sample, seed coats were removed from the cotyledons after soaking for $12 \mathrm{~h}$ in distilled water. The extract of each fraction (seed coat and cotyledon) was prepared using the method described by Xu et al. (2007) with some modifications. Three grams of each fraction were ground separately (NutriBullet NBR-12XX, Los Angeles, California, USA), $25 \mathrm{~mL}$ of an acetone/water/acetic acid mixture (70:29.5:0.5, v/v/v) was added, and the mixture was homogenized (Wisetis Homogenizer, HG-15-A, 110 v; DAIHAN-brand, Gangwon, Korea) for 20 s. Finally, the fractions were centrifuged at $4000 \mathrm{rpm}$ for $20 \mathrm{~min}$ (Hettich Centrifuge, Universal 32R, Tuttlingen, Germany), the supernatant was removed, and the same procedure was performed with the residue under the same conditions. Finally, the supernatants from each fraction were pooled to evaluate the antioxidant compounds.

\section{Polyphenols, flavonoids, anthocyanins and antioxidant activity (DPPH)}

The polyphenol concentration was evaluated using the Folin-Ciocalteu reagent following the method described by Singleton and Rossi (1965). Quantification was performed using a standard curve of gallic acid $\left(0.02\right.$ to $\left.0.16 \mathrm{mg} \mathrm{mL}^{-1} ; \mathrm{r}^{2}=0.99\right)$ and was reported as $\mathrm{mg}$ of gallic acid equivalents per gram of dry weight ( $\left.\mathrm{mg} \mathrm{GAE} \mathrm{g}^{-1} \mathrm{dw}\right)$. The method proposed by Zhishen et al. (1999) was used to measure the flavonoid content with a standard curve of catechin $\left(0.2\right.$ to $\left.0.12 \mathrm{mg} \mathrm{mL}^{-1} ; \mathrm{r}^{2}=0.99\right)$, and the results were expressed as $\mathrm{mg}$ of catechin equivalents per gram of dry weight ( $\mathrm{mg} \mathrm{CE} \mathrm{g}^{-1} \mathrm{dw}$ ).

The monomeric anthocyanin (MA) content was quantified using the differential pH method (Wrolstad, 1976). The sample extract was diluted 1:5 in a potassium chloride solution $(0.025 \mathrm{M}, \mathrm{pH}=1.0)$, and a second dilution was then performed with sodium acetate $(0.4 \mathrm{M}, \mathrm{pH}=4.5)$. In both dilutions, the absorbance was recorded over a range from 460 $\mathrm{nm}$ to $710 \mathrm{~nm}$ (Spectrophotometer UV-1800, Shimadzu, Kyoto, Japan), and the absorbance peak ( $\lambda$ vis-max) was taken as reference. The MA concentration was calculated using the formula $M A=(A \times M W \times D F \times 1000) /(\varepsilon \times l)$, where the absorbance of the sample is $A=\left(\mathrm{A}_{\lambda 510}-\mathrm{A}_{\lambda 710}\right)_{\mathrm{pH}}=1.0-\left(\mathrm{A}_{\left.\lambda 510-\mathrm{A}_{\lambda 710}\right)_{\mathrm{pH}}=4.5}, M W=449.2\right.$ is the molecular weight, $\varepsilon=26900$ is the cyanidin-3-glucoside molar absorptivity, $D F$ is the dilution factor employed, and $l$ is the cell length $(1=1 \mathrm{~cm})$. The results were reported as $\mathrm{mg}$ of cyanidin-3-glucoside per gram of dry weight (mg C3 $\mathrm{G} \mathrm{g}^{-1} \mathrm{dw}$ ).

The antioxidant activity was determined using the method of Brand-Williams et al. (1995) using the 2,2-diphenyl1-picrylhydrazyl (DPPH) free radical. For quantification, a standard Trolox (6-hydroxy-2,5,7,8-tetramethylchroman-2carboxylic acid) curve ( 0.10 to $0.80 \mu \mathrm{mol}$ Trolox $\left.\mathrm{mL}^{-1} ; \mathrm{r}^{2}=0.99\right)$ was used, and the results were reported as $\mu \mathrm{mol}$ equivalents of Trolox per gram of dry weight $\left(\mu \mathrm{mol} \mathrm{TE} \mathrm{g}^{-1} \mathrm{dw}\right)$.

\section{Statistical analysis}

Variance analyses were performed using a linear model of randomized blocks to evaluate differences within cropping seasons, origin regions of the population, populations within each region (nested population) and the interactions of the cropping seasons-regions and cropping seasons-populations for all variables evaluated. In these analyses, the commercial varieties were considered the control group. Additionally, multiple comparisons of means were performed using Tukey's test $(\mathrm{P}<0.05)$. The description of the cropping season-population interactions within each geographical origin group was represented in a dispersion plot. All statistical analyses were performed using SAS version 9.0 (SAS Institute, Cary, North Carolina, USA).

\section{RESULTS AND DISCUSSION}

The total polyphenol, flavonoid, and anthocyanin contents and the antioxidant activity (DPPH) of the seed coats and cotyledons were significantly different $(\mathrm{P}<0.05)$ between seasons, years of cultivation and regions of origin of the populations or samples as well as between populations within each region and their interactions (Table 1). A similar 
effect of the year and locality or crop environment on the contents of protein, starch, amylose, amylopectin, sucrose, malic acid and citric acid was also documented by Florez et al. (2009) in common bean landraces cultivated in different regions of Spain, where variety-location and variety-year had significant effects on the seed composition. This finding indicates that the agroecological conditions of the crop significantly affect the phenolic compound content of the seeds of legumes such as beans.

The season and year of cultivation (environment) had a significant effect on the phenolic content and antioxidant activity (DPPH) of the bean seeds despite being planted in the same plot for both seasons (Table 2). For example, during the 2014 season, higher averages were measured in total polyphenols and monomeric anthocyanins compared to the averages from the 2015 season. Conversely, in 2015, higher total flavonoid content and antioxidant activity (DPPH) were determined. This finding suggests that there is a strong environmental effect on the composition of the bean seed. Differences in seed composition from one season to another were also evident in the color indexes, in which the brightness $\left(\mathrm{L}^{*}\right)$ and hue $\left(\mathrm{h}^{\circ}\right)$ were higher in 2015 than in 2014.

The evaluated bean populations (except for the controls) were obtained from farmers in different geographic regions of Oaxaca, Mexico. Because distances between the communities of origin were greater than $100 \mathrm{~km}$, we could infer that bean populations were genetically divergent to a certain extent due to their divergent geographic and likely genealogical origins. These differences between groups of samples by geographic origin are presented in Table 2. For example,

Table 1. Significance of square means of the analyses of variances in flavonoid, polyphenol, and anthocyanin contents, antioxidant activity and color indexes evaluated in common bean seeds.

\begin{tabular}{|c|c|c|c|c|c|c|c|c|}
\hline \multirow[b]{2}{*}{ Seed fraction } & \multirow[b]{2}{*}{$\begin{array}{l}\text { Variable } \\
\text { evaluated }\end{array}$} & \multicolumn{6}{|c|}{ Sources of variation } & \multirow[b]{2}{*}{$\mathrm{CV}(\%$} \\
\hline & & $\begin{array}{l}\text { Crop cycle } \\
\text { (CC) }\end{array}$ & $\begin{array}{l}\text { Origin } \\
\text { regions }(\mathrm{R})\end{array}$ & $\begin{array}{c}\text { Populations/ } \\
\text { region }(\mathrm{Pob} / \mathrm{R})^{1}\end{array}$ & $\mathrm{CC} \times \mathrm{R}$ & $\mathrm{CC} \times \mathrm{Pob} / \mathrm{R}$ & Error & \\
\hline \multirow[t]{4}{*}{ Seed coat } & $\mathrm{TPol}^{2}$ & $33201.6^{*}$ & $13046.5^{*}$ & $14618.7 * *$ & $3472.9 * *$ & $2338.6 * *$ & 4.1 & 2.4 \\
\hline & TFlav & $217.4 * *$ & $461.5 * *$ & $178.2 * *$ & $57.0 * *$ & $32.7 * *$ & 0.05 & 2.0 \\
\hline & MAntho & $0.54 * *$ & $16.10 * *$ & $16.01^{* *}$ & $0.27 * *$ & $1.49 * *$ & 0.006 & 5.8 \\
\hline & AAct & $1972887 * *$ & $1972883 * *$ & $890192 * *$ & $38500 * *$ & $136663^{* *}$ & 143.04 & 1.6 \\
\hline \multirow[t]{3}{*}{ Cotyledons } & TPol & $31.29 * *$ & $1.85^{* *}$ & $10.49 * *$ & $4.02 * *$ & $10.75 * *$ & 0.005 & 3.3 \\
\hline & TFlav & $0.25 * *$ & $0.26 * *$ & $0.60 * *$ & $0.02 *$ & $0.16 * *$ & 0.01 & 27.0 \\
\hline & AAct & $504.7 *$ & $374.5 * *$ & $596.6 * *$ & $11.6 * *$ & $226.2 * *$ & 0.1 & 3.0 \\
\hline \multirow[t]{3}{*}{ Seed coat color } & $\mathrm{L}^{*}$ & $730.8^{* *}$ & $392.0 * *$ & $526.2 * *$ & $113.5^{* *}$ & $63.6 * *$ & 25.6 & 9.2 \\
\hline & $\mathrm{C}^{*}$ & $0.08 \mathrm{~ns}$ & $3.20 * *$ & $3.60 * *$ & $0.71^{\mathrm{ns}}$ & $0.38^{\mathrm{ns}}$ & 0.33 & 20.6 \\
\hline & $h^{\circ}$ & $1213.2 * *$ & $2672.2 * *$ & $1469.8 * *$ & $410.7 * *$ & $416.1 * *$ & 103.03 & 16.4 \\
\hline
\end{tabular}

${ }^{1} \mathrm{Pob} / \mathrm{R}$ : Populations nested in regions of origin; CV: coefficient of variation.

${ }^{2}$ TPol: total polyphenols; TFlav: total flavonoids; MAntho: monomeric anthocyanins; AAct: antioxidant activity; L*: brightness; C*: chroma; $\mathrm{h}^{\circ}$ : hue angle.

${ }^{\mathrm{n}}$ Nonsignificant $(\mathrm{P}>0.05) ;$ * Significant at $\mathrm{P}<0.05$; **Significant at $\mathrm{P}<0.01$.

Table 2. Comparison of means for cropping seasons and groups of origin regions of the common bean populations evaluated.

\begin{tabular}{|c|c|c|c|c|c|c|c|c|}
\hline \multirow[b]{2}{*}{ Seed fraction } & \multirow[b]{2}{*}{$\begin{array}{l}\text { Variable } \\
\text { evaluated }\end{array}$} & \multicolumn{2}{|c|}{ Crop season } & \multicolumn{5}{|c|}{ Origins of the common beans populations and controls } \\
\hline & & 2014 & 2015 & $\begin{array}{l}\text { Mixteca } \\
(\mathrm{n}=26)\end{array}$ & $\begin{array}{l}\text { Sierra Norte } \\
(\mathrm{n}=10)\end{array}$ & $\begin{array}{l}\text { Sierra Sur } \\
(\mathrm{n}=8)\end{array}$ & $\begin{array}{c}\text { Valles } \\
\text { Centrales } \\
(\mathrm{n}=10)\end{array}$ & $\begin{array}{c}\text { Improved } \\
\text { varieties } \\
(\mathrm{n}=5)\end{array}$ \\
\hline \multirow[t]{4}{*}{ Seed coat } & TPol $^{1}$ & $96.70 \mathrm{a}^{2}$ & $73.70 \mathrm{~b}$ & $83.70 \mathrm{c}$ & $104.70 \mathrm{a}$ & $70.80 \mathrm{e}$ & $77.00 \mathrm{~d}$ & $93.50 \mathrm{~b}$ \\
\hline & TFlav & $10.55 b$ & $12.10 \mathrm{a}$ & $12.07 \mathrm{~b}$ & $13.30 \mathrm{a}$ & $8.60 \mathrm{~d}$ & $11.97 \mathrm{c}$ & $6.57 \mathrm{e}$ \\
\hline & MAntho & $1.36 \mathrm{a}$ & $1.26 \mathrm{~b}$ & $0.93 \mathrm{e}$ & $1.80 \mathrm{~b}$ & $1.50 \mathrm{c}$ & $1.36 \mathrm{~d}$ & $1.87 \mathrm{a}$ \\
\hline & AAct & $660.90 \mathrm{~b}$ & $815.60 \mathrm{a}$ & $726.90 \mathrm{~b}$ & $989.50 \mathrm{a}$ & $635.10 \mathrm{~d}$ & $713.20 \mathrm{c}$ & $510.10 \mathrm{e}$ \\
\hline \multirow[t]{3}{*}{ Cotyledons } & TPol & $2.53 \mathrm{a}$ & $1.76 \mathrm{~b}$ & $2.26 \mathrm{a}$ & $1.99 \mathrm{~d}$ & $1.95 \mathrm{e}$ & $2.17 \mathrm{~b}$ & $2.10 \mathrm{c}$ \\
\hline & TFlav & $0.35 b$ & $0.39 \mathrm{a}$ & $0.42 \mathrm{a}$ & $0.34 \mathrm{~b}$ & $0.33 b$ & $0.33 b$ & $0.30 \mathrm{~b}$ \\
\hline & AAct & $9.57 \mathrm{~b}$ & $11.75 \mathrm{a}$ & $12.33 \mathrm{a}$ & $10.02 \mathrm{c}$ & $9.33 \mathrm{~d}$ & $10.19 b$ & $6.32 \mathrm{e}$ \\
\hline \multirow[t]{3}{*}{ Seed coat color } & $\mathrm{L}^{*}$ & $53.50 \mathrm{~b}$ & $56.10 \mathrm{a}$ & $54.80 \mathrm{bc}$ & $52.90 \mathrm{c}$ & $58.30 \mathrm{a}$ & $52.80 \mathrm{c}$ & $56.70 \mathrm{ab}$ \\
\hline & $C^{*}$ & $8.54 \mathrm{a}$ & $8.55 \mathrm{a}$ & $9.58 \mathrm{a}$ & $7.34 \mathrm{c}$ & $7.52 b c$ & $7.45 b c$ & $9.40 \mathrm{ab}$ \\
\hline & $\mathrm{h}^{\circ}$ & $60.30 \mathrm{~b}$ & $63.80 \mathrm{a}$ & $59.60 \mathrm{~cd}$ & $63.50 \mathrm{bc}$ & $71.80 \mathrm{a}$ & $56.70 \mathrm{~d}$ & $66.90 \mathrm{~b}$ \\
\hline
\end{tabular}

${ }^{1}$ TPol: Total polyphenols (mg gallic acid equivalents $\mathrm{g}^{-1}$ dry weight, $\mathrm{dw}$ ); TFlav: flavonoids (mg catechin equivalents $\mathrm{g}^{-1} \mathrm{dw}$ ); MAntho: monomeric anthocyanins (mg cyanidin-3-glucoside $\left.\mathrm{g}^{-1} \mathrm{dw}\right)$; AAact: antioxidant activity ( $\mu$ mol Trolox equivalents $\mathrm{g}^{-1} \mathrm{dw}$ ) $\mathrm{L}^{*}$ : brightness; $\mathrm{C}^{*}$ : chroma; $h^{\circ}$ : hue angle.

${ }^{2}$ In row, between cropping seasons and among populations origins; means with the same letter are not significantly different according to Tukey's test $(\mathrm{P}<0.05)$. 
bean populations originating in the Sierra Norte showed significantly higher averages of total polyphenols, flavonoids and antioxidant activity (DPPH) in the seed coats than the populations with other origins. In this study, the average anthocyanin contents were higher in the control group than among the populations grouped by geographic origin. Another characteristic pattern observed was that the Mixteca populations had higher total polyphenol and flavonoid concentrations and antioxidant activity (DPPH) in the cotyledons than the controls and populations with other origins.

The results show that the genotype, improved variety or landrace with different geographic and genealogical origins influence the phenolic compound content and antioxidant activity (DPPH) of the bean seed coats and cotyledons. Similar effects in relation to the content of phenolic compounds and antioxidant activity have been reported in common bean genotypes from the USA and Mexican landraces evaluated with respect to seed color and region of origin (Akond et al., 2011; Aquino-Bolaños et al., 2016). These authors reported that the stability of the phenol and flavonoid contents by locality or site of cultivation depended on fixed characteristics in the variety that were related to the seed composition; they also detected biophysical changes in bean seed color (Table 2).

Table 3 presents the average polyphenol, flavonoid and anthocyanin contents and antioxidant activity (DPPH) per bean population, including the controls, when grouped by region of geographic origin, and in this case, we used the value of honest significant differences (HSD) of Tukey's test to evaluate the differences between two means $(\mathrm{P}<0.05)$. Notable populations in all evaluated parameters were identified within each group (e.g., populations with a black-colored seed coat [Pob-41, Pob-31, Pob-4, Pob-08 and Pob-66] or with mixtures of seed colors [Pob-32, Pob-20, Pob-22, Pob-26 and Pob69]). This result indicates that landraces can be selected to implement strategies for the direct utilization of outstanding bean populations in each region of origin to improve family nutrition. Additionally, local genetic improvement actions assisted by biochemical assessments can be implemented to identify and select populations with higher functional and nutraceutical component values and stability.

Among the populations within each group of geographic origin, we determined a high level of variability in the flavonoid, polyphenol and anthocyanin contents and antioxidant activity (DPPH) in the seed coats and cotyledons. Different seed coat colors were seen within each group of origin and group of controls. For example, the Valles Centrales group includes populations with black, red, yellow, and white seed coats; the Sierra Norte group included populations with a black color and mixtures of colors; the Sierra Sur group contained populations of red, black and mixed colors as well as populations that were white or without color; and the Mixteca group, which included the largest number of populations (16), was identified with black, yellow, red, mixed colors, pinto, and white colorations (Table 4). The seed coat color was a determining factor in the polyphenol, flavonoid and monomeric anthocyanin contents and the antioxidant activity (DPPH) in each evaluated population. The general pattern in these compounds from highest to lowest was as follows: black seed coat $\geq$ seed color mixture $>$ red $\geq$ yellow $\geq$ pinto $>$ white or without pigment. This pattern was also detected by Akond et al. (2011) in common beans. Thus, the consumption of pigmented beans with a black, red or purple color is recommended. Therefore, the Sierra Norte group was outstanding because it included populations with either only black or only mixed color seed coats with higher average contents of antioxidant compounds than the other groups.

The comparison of the polyphenol and flavonoid contents and antioxidant activity (DPPH) in the seed coats and cotyledons of each population strongly associated pigmented seed coats with these characteristics, since they did not differ in the populations with white seed coats (Table 4). Notably, black or mixed color populations with greater or equal phenolic contents than the improved varieties used as the controls could be selected from each source. The great advantage of landraces is greater access to the seed by farmers because they can be obtained by exchange, purchase or barter between neighbors and without direct cost, whereas the improved varieties can only be purchased.

Generally, the Pob-61, Pob-20, Pob-22 and Pob-26 populations had high total polyphenol (> $\left.165 \mathrm{mg} \mathrm{GAE} \mathrm{g}^{-1} \mathrm{dw}\right)$ and flavonoid (> $14 \mathrm{mg} \mathrm{CE} \mathrm{g}^{-1} \mathrm{dw}$ ) concentrations in the seed coats (Table 4). These concentrations were higher than those reported by Aquino-Bolaños et al. (2016) for beans grown in Oaxaca, Mexico, with values of $127 \mathrm{mg} \mathrm{GAE} \mathrm{g}^{-1} \mathrm{dw}$ for total polyphenols and $11 \mathrm{mg} \mathrm{CE} \mathrm{g}^{-1} \mathrm{dw}$ for flavonoids. The highest antioxidant activity (DPPH) in the seed coats was not always associated with the populations that had higher flavonoid, polyphenol and anthocyanin contents. This finding indicates that antioxidant activity (DPPH) does not only depend on the concentrations of these compounds as reported by Oomah et al. (2005).

Native and improved black bean populations showed the highest values of monomeric anthocyanins (1.63 to 6.71 mg C3GE g-1 $\mathrm{dw}$ ). The highest value was quantified in the improved Black Horse variety, and the next highest value 
Table 3. Variation in phenolic compounds, antioxidant activity and seed coat color in Mexican populations of common beans.

\begin{tabular}{|c|c|c|c|c|c|c|c|c|c|c|c|}
\hline \multirow{2}{*}{$\begin{array}{l}\text { Population } \\
\text { ID }^{1}\end{array}$} & \multirow[b]{2}{*}{ Origin regions } & \multicolumn{4}{|c|}{ Seed coat } & \multicolumn{3}{|c|}{ Cotyledons } & \multicolumn{3}{|c|}{ Seed coat color } \\
\hline & & $\mathrm{TP}$ & $\mathrm{TF}$ & MA & AA & TP & $\mathrm{TF}$ & AA & $\mathrm{L}^{*}$ & $\mathrm{C}^{*}$ & $\mathrm{~h}^{\mathrm{o}}$ \\
\hline Pob- $03^{R}$ & Valles Centrales & 86.5 & 13.85 & 0.82 & 865.6 & 2.77 & 0.31 & 12.8 & 48.6 & 8.0 & 54.8 \\
\hline Pob- $04^{\mathrm{N}}$ & V. Centrales & 94.4 & 11.00 & 2.49 & 945.7 & 2.07 & 0.36 & 10.7 & 47.1 & 4.0 & 64.3 \\
\hline Pob-05 ${ }^{\text {B }}$ & V. Centrales & 1.3 & 0.22 & 0.05 & 33.9 & 1.49 & 0.35 & 7.8 & 75.0 & 8.4 & 45.7 \\
\hline Pob- $06^{\mathrm{N}}$ & V. Centrales & 77.2 & 8.49 & 1.63 & 688.5 & 2.43 & 0.41 & 11.1 & 50.6 & 4.1 & 78.3 \\
\hline Pob-09R & V. Centrales & 82.2 & 17.46 & 0.58 & 817.0 & 2.22 & 0.26 & 9.6 & 48.7 & 9.9 & 40.9 \\
\hline Pob-39R & V. Centrales & 93.7 & 14.50 & 0.33 & 766.0 & 2.31 & 0.30 & 8.8 & 53.1 & 8.0 & 47.3 \\
\hline Pob- $40^{\mathrm{R}}$ & V. Centrales & 91.3 & 15.44 & 0.53 & 656.8 & 2.35 & 0.33 & 9.5 & 48.6 & 9.0 & 41.7 \\
\hline Pob- $41^{\mathrm{N}}$ & V. Centrales & 100.4 & 13.67 & 4.44 & 946.8 & 2.04 & 0.42 & 10.4 & 51.7 & 5.2 & 56.0 \\
\hline Pob- $49^{N}$ & V. Centrales & 92.8 & 12.71 & 2.70 & 894.0 & 2.01 & 0.28 & 10.0 & 47.6 & 4.9 & 77.4 \\
\hline Pob-57 ${ }^{\text {A }}$ & V. Centrales & 50.1 & 12.35 & 0.08 & 518.1 & 2.04 & 0.34 & 11.2 & 57.0 & 13.0 & 60.9 \\
\hline Pob- $29^{\mathrm{N}}$ & Sierra Norte & 102.8 & 11.34 & 3.54 & 985.5 & 2.18 & 0.39 & 10.1 & 47.9 & 3.7 & 67.2 \\
\hline Pob- $30^{\mathrm{N}}$ & Sierra Norte & 128.1 & 14.39 & 1.95 & 947.4 & 1.98 & 0.32 & 7.7 & 51.0 & 7.5 & 68.3 \\
\hline Pob-31 ${ }^{\mathrm{N}}$ & Sierra Norte & 177.6 & 13.73 & 1.77 & 1524.0 & 2.48 & 0.39 & 13.3 & 51.1 & 4.3 & 63.7 \\
\hline Pob-32M & Sierra Norte & 107.8 & 16.78 & 1.98 & 1059.4 & 1.24 & 0.26 & 7.0 & 60.3 & 5.6 & 69.4 \\
\hline Pob- $33^{\mathrm{M}}$ & Sierra Norte & 86.0 & 16.66 & 1.10 & 741.3 & 1.86 & 0.31 & 10.5 & 54.2 & 10.5 & 52.4 \\
\hline Pob-34 ${ }^{\mathrm{M}}$ & Sierra Norte & 64.8 & 9.26 & 0.31 & 771.2 & 1.93 & 0.31 & 11.3 & 60.8 & 10.6 & 61.5 \\
\hline Pob-35 ${ }^{\mathrm{M}}$ & Sierra Norte & 163.3 & 16.14 & 1.63 & 1569.9 & 2.17 & 0.34 & 12.5 & 48.4 & 5.0 & 49.5 \\
\hline Pob-43 $3^{\mathrm{M}}$ & Sierra Norte & 62.4 & 10.41 & 0.06 & 562.0 & 1.76 & 0.30 & 9.2 & 55.7 & 15.4 & 64.3 \\
\hline Pob- $44^{\mathrm{N}}$ & Sierra Norte & 71.1 & 8.30 & 3.27 & 645.1 & 2.55 & 0.44 & 12.0 & 50.4 & 6.2 & 67.3 \\
\hline Pob- $46^{\mathrm{N}}$ & Sierra Norte & 82.8 & 16.03 & 2.43 & 1089.8 & 1.75 & 0.33 & 6.5 & 49.3 & 4.6 & 71.5 \\
\hline Pob- $48^{N}$ & Sierra Sur & 107.0 & 14.16 & 2.91 & 1063.3 & 2.01 & 0.35 & 10.5 & 50.0 & 4.3 & 74.6 \\
\hline Pob- $02^{\text {B }}$ & Sierra Sur & 1.0 & 0.18 & 0.36 & 39.8 & 1.65 & 0.34 & 9.7 & 84.3 & 10.8 & 85.8 \\
\hline Pob-50 & Sierra Sur & 2.9 & 0.26 & 0.12 & 40.0 & 1.76 & 0.37 & 9.7 & 72.9 & 8.2 & 85.6 \\
\hline Pob-51 ${ }^{\mathrm{M}}$ & Sierra Sur & 88.2 & 11.75 & 1.52 & 740.7 & 1.77 & 0.33 & 9.4 & 53.7 & 12.2 & 63.2 \\
\hline Pob-52N & Sierra Sur & 96.5 & 9.50 & 2.37 & 986.8 & 2.36 & 0.30 & 10.4 & 46.3 & 4.5 & 76.6 \\
\hline Pob-54 ${ }^{\mathrm{R}}$ & Sierra Sur & 103.7 & 13.06 & 0.56 & 632.8 & 2.15 & 0.36 & 7.6 & 53.6 & 7.6 & 45.9 \\
\hline Pob-55 ${ }^{\mathrm{N}}$ & Sierra Sur & 96.1 & 10.54 & 2.48 & 822.3 & 1.99 & 0.38 & 7.8 & 46.2 & 4.7 & 70.6 \\
\hline Pob- $56^{\mathrm{M}}$ & Sierra Sur & 71.4 & 9.33 & 1.70 & 755.4 & 1.88 & 0.26 & 9.5 & 59.9 & 7.9 & 71.6 \\
\hline Pob- $08^{N}$ & Mixteca & 118.7 & 8.09 & 3.19 & 857.4 & 2.09 & 0.35 & 10.7 & 45.6 & 4.5 & 71.1 \\
\hline Pob-11 ${ }^{\mathrm{A}}$ & Mixteca & 63.7 & 13.23 & 0.06 & 603.8 & 1.91 & 0.33 & 8.7 & 63.7 & 14.8 & 66.9 \\
\hline Pob-13N & Mixteca & 101.1 & 7.84 & 2.67 & 842.8 & 2.28 & 0.29 & 10.8 & 44.8 & 4.5 & 69.8 \\
\hline Pob-17 ${ }^{\mathrm{M}}$ & Mixteca & 49.5 & 7.59 & 0.13 & 325.6 & 1.82 & 0.33 & 10.6 & 56.1 & 8.3 & 65.5 \\
\hline Pob- $18^{N}$ & Mixteca & 91.2 & 9.39 & 3.13 & 781.3 & 2.22 & 0.43 & 11.8 & 47.2 & 4.0 & 70.1 \\
\hline Pob-19R & Mixteca & 41.3 & 12.57 & 0.21 & 500.8 & 1.21 & 2.34 & 73.1 & 52.0 & 11.3 & 34.4 \\
\hline Pob- $20^{\mathrm{M}}$ & Mixteca & 168.7 & 17.16 & 0.74 & 1491.4 & 2.23 & 0.38 & 10.8 & 53.9 & 14.6 & 63.1 \\
\hline Pob- $22^{\mathrm{M}}$ & Mixteca & 163.3 & 20.74 & 0.49 & 930.6 & 1.73 & 0.68 & 12.2 & 57.6 & 8.3 & 65.4 \\
\hline Pob-23 ${ }^{\mathrm{M}}$ & Mixteca & 67.8 & 10.76 & 1.81 & 694.7 & 1.91 & 0.31 & 10.5 & 50.5 & 10.2 & 64.2 \\
\hline Pob-26 ${ }^{\mathrm{M}}$ & Mixteca & 180.5 & 20.77 & 0.53 & 1564.4 & 2.15 & 0.38 & 13.8 & 57.2 & 6.6 & 68.6 \\
\hline Pob- $28^{\mathrm{R}}$ & Mixteca & 75.4 & 12.38 & 0.45 & 540.2 & 2.22 & 0.29 & 8.0 & 52.8 & 7.3 & 48.4 \\
\hline Pob- $58^{\mathrm{R}}$ & Mixteca & 47.2 & 12.57 & 0.22 & 633.2 & 2.06 & 0.31 & 9.4 & 47.1 & 11.9 & 39.5 \\
\hline Pob-59A & Mixteca & 50.3 & 12.79 & 0.07 & 519.8 & 1.61 & 0.26 & 9.4 & 57.8 & 24.3 & 69.4 \\
\hline Pob- $61^{\mathrm{N}}$ & Mixteca & 95.2 & 10.51 & 3.16 & 879.0 & 1.93 & 0.39 & 7.8 & 47.7 & 4.5 & 78.9 \\
\hline Pob- $62^{R}$ & Mixteca & 81.9 & 14.90 & 0.24 & 671.6 & 1.96 & 0.31 & 8.4 & 52.6 & 11.4 & 37.8 \\
\hline Pob- $63^{R}$ & Mixteca & 56.6 & 12.07 & 0.08 & 556.6 & 1.87 & 0.28 & 8.4 & 53.5 & 10.5 & 41.0 \\
\hline Pob- $64^{\mathrm{R}}$ & Mixteca & 90.0 & 14.73 & 0.22 & 699.9 & 2.27 & 0.37 & 8.2 & 53.9 & 8.4 & 31.4 \\
\hline Pob- $65^{\text {A }}$ & Mixteca & 67.7 & 16.32 & 0.04 & 509.2 & 1.66 & 0.29 & 10.4 & 58.1 & 18.6 & 71.7 \\
\hline Pob- $66^{\mathrm{N}}$ & Mixteca & 108.6 & 11.01 & 3.98 & 909.8 & 2.34 & 0.38 & 13.0 & 52.6 & 5.1 & 65.4 \\
\hline Pob-67 & Mixteca & 1.2 & 0.18 & 0.01 & 19.8 & 1.62 & 0.34 & 8.1 & 72.4 & 7.4 & 83.9 \\
\hline Pob- $68^{P}$ & Mixteca & 63.5 & 7.19 & 0.58 & 688.5 & 1.58 & 0.30 & 9.7 & 57.4 & 6.9 & 74.5 \\
\hline Pob-69M & Mixteca & 120.3 & 17.80 & 1.13 & 1331.5 & 1.94 & 0.43 & 10.5 & 63.8 & 6.1 & 56.0 \\
\hline Pob-71 ${ }^{\mathrm{M}}$ & Mixteca & 77.0 & 7.92 & 0.28 & 718.6 & 1.49 & 0.32 & 9.5 & 57.2 & 6.2 & 53.7 \\
\hline Pob-72 ${ }^{\mathrm{M}}$ & Mixteca & 65.9 & 13.87 & 0.43 & 620.9 & 1.79 & 0.32 & 7.0 & 53.9 & 12.5 & 55.1 \\
\hline Pob-74 ${ }^{\mathrm{M}}$ & Mixteca & 52.8 & 7.63 & 0.27 & 402.9 & 1.75 & 0.28 & 11.0 & 64.1 & 9.3 & 66.0 \\
\hline Pob-76R & Mixteca & 76.2 & 13.96 & 0.16 & 606.0 & 2.19 & 0.32 & 8.8 & 50.3 & 11.4 & 37.2 \\
\hline \multicolumn{12}{|c|}{ Controls or improved varieties } \\
\hline \multicolumn{2}{|c|}{ Flor de Mayo (cream-pink) } & 153.8 & 17.87 & 0.27 & 622.8 & 2.61 & 0.32 & 4.6 & 65.3 & 7.0 & 46.3 \\
\hline \multicolumn{2}{|c|}{ Black Horse } & 182.9 & 4.90 & 6.71 & 912.8 & 2.45 & 0.26 & 6.4 & 46.4 & 3.2 & 55.3 \\
\hline \multicolumn{2}{|c|}{ Negro Tropical (black) } & 68.5 & 6.33 & 2.36 & 629.6 & 2.27 & 0.39 & 12.0 & 45.1 & 5.7 & 82.4 \\
\hline \multicolumn{2}{|c|}{ Peruano (sandy-yellow) } & 28.4 & 1.02 & 0.03 & 177.8 & 1.50 & 0.25 & 3.7 & 64.1 & 20.6 & 86.2 \\
\hline \multicolumn{2}{|c|}{ Pinto (beige-and-reddish) } & 34.1 & 2.71 & 0.00 & 207.6 & 1.69 & 0.26 & 4.9 & 62.9 & 10.5 & 64.2 \\
\hline \multicolumn{2}{|c|}{ HSD-Tukey } & 4.1 & 0.46 & 0.16 & 24.6 & 0.15 & 0.21 & 0.67 & 10.4 & 8.8 & 20.8 \\
\hline
\end{tabular}

TP: Total polyphenols (mg gallic acid equivalents $\mathrm{g}^{-1}$ dry weight, dw); TF: flavonoids (mg catechin equivalents $\mathrm{g}^{-1}$ dw); MA: monomeric anthocyanins (mg cyanidin-3-glucoside $\mathrm{g}^{-1} \mathrm{dw}$ ); AA: antioxidant activity ( $\mu$ mol Trolox equivalents $\mathrm{g}^{-1} \mathrm{dw}$ ); $\mathrm{L}^{*}$ : brightness; $\mathrm{C}^{*}$ : chroma; ${ }^{\circ}$ : hue angle. ${ }^{1}$ Visible color of seed, ID suffix: B: white, N: black, R: red, A: yellow, RS: pink, P: brindle, M: mix of colors (grains with colors red, white, black, purple, brindle, yellow, pink, brown, etc.) HSD = honest significant difference (HSD) of Tukey's test (P<0.05). 
Table 4. Comparison of means respect for interaction cropping seasons and origin regions of common bean populations.

\begin{tabular}{|c|c|c|c|c|c|c|c|}
\hline \multirow[b]{2}{*}{ Evaluated variables } & \multirow[b]{2}{*}{$\begin{array}{l}\text { Crop } \\
\text { season }\end{array}$} & \multicolumn{5}{|c|}{ Geographic origin of the common bean populations } & \multirow[b]{2}{*}{$\begin{array}{l}\text { HSD- } \\
\text { Tukey }\end{array}$} \\
\hline & & Mixteca & $\begin{array}{l}\text { Sierra } \\
\text { Norte }\end{array}$ & $\begin{array}{c}\text { Sierra } \\
\text { Sur }\end{array}$ & $\begin{array}{c}\text { Valles } \\
\text { Centrales }\end{array}$ & Controls & \\
\hline \multirow[t]{2}{*}{ Total polyphenols in seed coat, $\mathrm{mg} \mathrm{GAE} \mathrm{g}^{-1} \mathrm{dw}$} & 2014 & 98.70 & 117.00 & 86.30 & 81.80 & 92.20 & \multirow[t]{2}{*}{1.52} \\
\hline & 2015 & 68.60 & 92.30 & 55.40 & 72.20 & 94.90 & \\
\hline \multirow[t]{2}{*}{ Total polyphenols in cotyledons, $\mathrm{mg} \mathrm{GAE} \mathrm{g}^{-1} \mathrm{dw}$} & 2014 & 2.82 & 2.29 & 2.24 & 2.51 & 2.02 & \multirow[t]{2}{*}{0.05} \\
\hline & 2015 & 1.71 & 1.69 & 1.66 & 1.84 & 2.18 & \\
\hline \multirow[t]{2}{*}{ Total flavonoids in seed coat, $\mathrm{mg} \mathrm{CE} \mathrm{g}^{-1} \mathrm{dw}$} & 2014 & 11.53 & 11.11 & 8.63 & 11.10 & 6.36 & \multirow[t]{2}{*}{0.17} \\
\hline & 2015 & 12.62 & 15.50 & 8.56 & 12.84 & 6.77 & \\
\hline \multirow[t]{2}{*}{ Total flavonoids in cotyledons, $\mathrm{mg} \mathrm{CE} \mathrm{g}^{-1} \mathrm{dw}$} & 2014 & 0.40 & 0.30 & 0.29 & 0.33 & 0.27 & \multirow[t]{2}{*}{0.07} \\
\hline & 2015 & 0.44 & 0.37 & 0.39 & 0.34 & 0.32 & \\
\hline \multirow[t]{2}{*}{ Monomeric anthocyanins in seed coat, $\mathrm{mg} \mathrm{C} 3 \mathrm{G} \mathrm{g}^{-1} \mathrm{dw}$} & 2014 & 1.00 & 1.90 & 1.59 & 1.35 & 1.82 & \multirow[t]{2}{*}{0.06} \\
\hline & 2015 & 0.87 & 1.71 & 1.41 & 1.38 & 1.93 & \\
\hline \multirow{2}{*}{ Antioxidant activity in seed coat, $\mu \mathrm{mol} \mathrm{TE} \mathrm{g}^{-1} \mathrm{dw}$} & 2014 & 646.00 & 902.60 & 594.50 & 614.20 & 455.20 & \multirow{2}{*}{9.04} \\
\hline & 2015 & 807.90 & 1076.50 & 675.80 & 812.30 & 565.00 & \\
\hline \multirow[t]{2}{*}{ Antioxidant activity in cotyledons, $\mu \mathrm{mol} \mathrm{TE} \mathrm{g}^{-1} \mathrm{dw}$} & 2014 & 11.50 & 8.30 & 8.00 & 9.10 & 5.30 & \multirow[t]{2}{*}{0.24} \\
\hline & 2015 & 13.20 & 11.70 & 10.60 & 11.20 & 7.30 & \\
\hline \multirow[t]{2}{*}{$\mathrm{L}^{*}$, brightness } & 2014 & 54.20 & 50.30 & 57.10 & 50.20 & 56.80 & \multirow[t]{2}{*}{3.82} \\
\hline & 2015 & 55.30 & 55.50 & 59.60 & 55.40 & 56.70 & \\
\hline \multirow[t]{2}{*}{$\mathrm{C}^{*}$, chroma } & 2014 & 9.70 & 6.60 & 7.00 & 8.40 & 9.40 & \multirow[t]{2}{*}{3.23} \\
\hline & 2015 & 9.50 & 8.10 & 8.10 & 6.50 & 9.40 & \\
\hline \multirow[t]{2}{*}{$\mathrm{h}^{\circ}$, Hue angle } & 2014 & 58.70 & 61.10 & 71.00 & 51.20 & 67.70 & \multirow[t]{2}{*}{7.67} \\
\hline & 2015 & 60.50 & 66.00 & 72.60 & 62.20 & 66.10 & \\
\hline
\end{tabular}

GAE: Gallic acid equivalents; CE: catechin equivalents; C3G: cyanidin-3-glucoside; TE: trolox equivalents; HSD: honest significant difference (HSD) of Tukey's test $(\mathrm{P}<0.05)$.

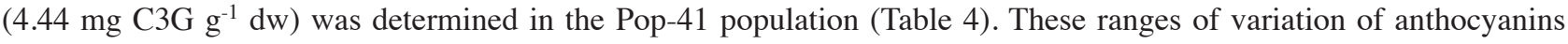
coincided with the ranges reported by Kan et al. (2016) in common bean seed coats grown in the Shandong and Jiangxi

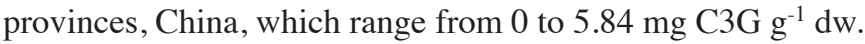

Similar to the studies of Akond et al. (2011) and Kan et al. (2016), the anthocyanin contents in the black, red, purple and mixed pigmented beans in this study were higher than the contents in the populations with light-colored seed coats, such as yellow, pinto and white. Although specific anthocyanin groups not were identified in this work, previous studies found higher concentrations of cyanidin-3-glucoside and delphinidin-3-glucoside in black beans, and petunidin-3-glucoside, delphinidin and malvidine-3-glucoside in beans with pink, yellow and black seed coats. Conversely, flavonoids but not anthocyanins were detected in light-colored beans, such as cream or white (Chen et al., 2015; Mojica et al., 2015; Kan et al., 2016).

The polyphenol and flavonoid contents and the antioxidant activity (DPPH) in the cotyledons were similar within each group of origin. This finding is the largest difference observed between and within each origin group. Due to the separation of the cotyledons from the seed coats and the concentration of more phenolic compounds in the seed coats, the antioxidant activity (DPPH) in the cotyledon extracts was lower than that in the seed coats. This finding also indicates that the antioxidant activity (DPPH) in the cotyledons has great importance in all pigmented seeds; for example, the highest antioxidant activity (DPPH) value was $73.1 \mu \mathrm{mol} \mathrm{TE} \mathrm{g}^{-1} \mathrm{dw}$ in the Pob-19 population with red seed coats (Table 4). However, polyphenols are almost always present in seed coats and are detected at lower levels in the cotyledons (Dueñas et al., 2006; Chel-Guerrero et al., 2012; Ombra et al., 2016).

The use of color parameters $\left(\mathrm{L}^{*}, \mathrm{C}^{*}\right.$ and $\mathrm{h}^{\circ}$ ) was useful for differentiating bean populations according to seed coat color. Brightness $\left(\mathrm{L}^{*}\right)$ values ranged from 44.9 to 94.3 , and the chroma index $\left(\mathrm{C}^{*}\right)$ oscillated between 3.7 and 24.3. The hue angle $\left(\mathrm{h}^{\circ}\right)$ was the most accurate parameter used to assign a point value to each gradual color or variant, with values ranging from 31.4 to 85.8 (Table 4). Based on these results, the evaluations in other similar studies and the visual reference of the seed coats themselves, the genotypes can be classified as a function of the hue angle $\left(\mathrm{h}^{\circ}\right)$, phenolic compounds and antioxidant activity (DPPH). Different population stability patterns were determined in the graphic descriptive analysis of the interactions of populations within each group of origin and crop cycle (Figure 1). In Figure 1, the dispersed populations in the upper left quadrant were those with the highest total polyphenol, flavonoid and anthocyanin contents in the seed in the 2015 cycle, whereas the populations with the highest contents in 2014 were dispersed in the lower right quadrant. Based on this analysis, the most stable populations are dispersed in the upper right quadrant with higher 
Figure 1. Scatterplot of common bean populations according to crop cycle and geographic origin, based on the contents

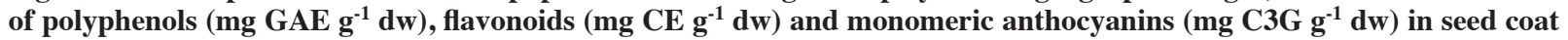
and cotyledons.

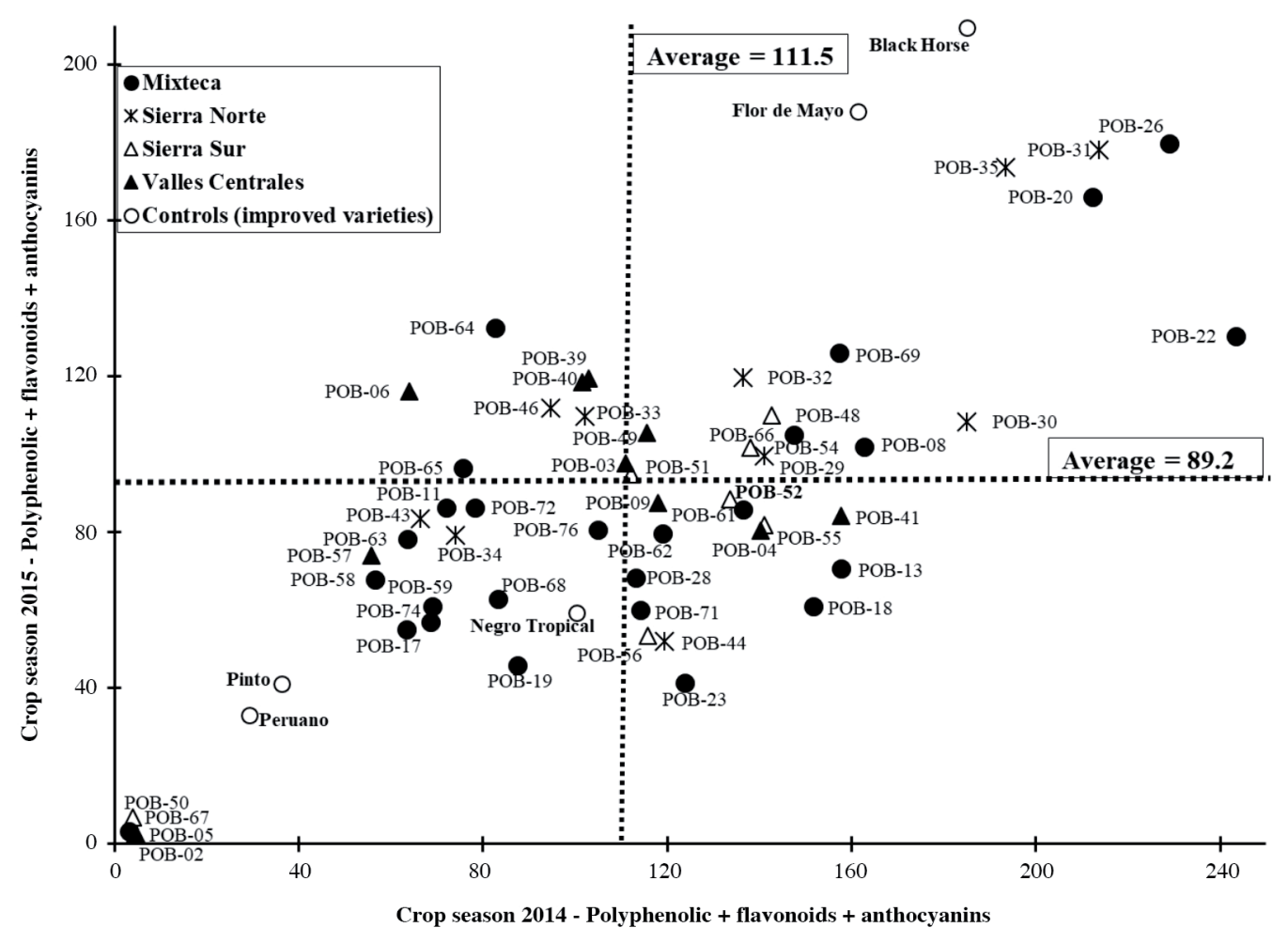

GAE: Gallic acid equivalents; CE: catechin equivalents; and C3G: cyanidin-3-glucoside.

phenolic compound contents in both cycles in relation to the average of each evaluation cycle. Hence, six native bean populations from the Mixteca region, five from the Sierra Norte, two from the Sierra Sur, one from the Valles Centrales, Oaxaca, Mexico, and two improved varieties (Black Horse and Flor de Mayo) stand out. The results show that a high number of native populations or improved common bean varieties were not stable in the synthesis and storage of phenolic compounds in the seed, and only 16 native populations and improved varieties (27.1\% of the total) were stable through two evaluation cycles.

In this work, genotypic and environmental effects on the phenolic compound contents and antioxidant activity (DPPH) of the seed coats and cotyledons of common beans were noted. In this regard, Barampama and Simard (1993), Bellato et al. (2013), López et al. (2013), and Chávez-Servia et al. (2016) indicated that the phenolic and micronutrient compound compositions in common bean seeds were strongly affected by the agroecological conditions, including cultivation and management by the farmer; the concentrations are not quantitatively inherited and are independent of the phenotypic similarities in seed coat color. In rural communities, farmers commonly select beans based on their taste, flavor or food preferences and genotypic adaptability to production agroecosystems (Espinosa-Alonso et al., 2006; Florez et al., 2009; Ombra et al., 2016).

Manach et al. (2004) noted that environmental factors, such as sunny days, soil type and precipitation, had an effect on the phenolic contents of plants. Low temperature can increase the production of phenolic compounds by increasing the synthesis of phenylalanine ammonia-lyase (PAL) in plants, whereas high altitudes (> $2000 \mathrm{~m}$ a.s.l.) and prolonged exposure to sunlight with UV radiation positively affect the synthesis of phenolic compounds (Kishore et al., 2010). These findings indicate that despite the variability in the environmental, genotypic and management characteristics that affect the seed composition of cultivated beans in different ecogeographic regions, some native populations and improved varieties can be chosen for immediate use among communities of farmers and thereby improve family nutrition. 


\section{CONCLUSIONS}

The evaluated populations of common beans and improved varieties (controls) showed differences in the phenol, flavonoid and anthocyanin compositions, in antioxidant activities (DPPH) and seed color parameters $\left(\mathrm{L}^{*}, \mathrm{C}^{*}\right.$ and $\left.\mathrm{h}^{\circ}\right)$. The geographical origins of the populations and cropping seasons significantly affected the compositions of the seed coats and cotyledons, and the regions of origin and populations had significant interactions with the crop cycle. The variability in the environmental, genotypic and management characteristics of the bean crops of populations with different ecogeographic origins influenced the composition and antioxidant activity (DPPH) of the bean seed. However, $27.1 \%$ of the total native populations and improved varieties (two controls) maintained stable seed compositions through cropping seasons. Among the populations, higher polyphenol and flavonoid concentrations and antioxidant activity (DPPH) were found in the seed coats than in cotyledons. These parameters were higher in populations with darkly pigmented seed coats (i.e., red, black, yellow or pinto) than in populations with light-colored seed coats. The genotype-environmental interactions effect in bioactive compounds provides insights for broadening the options in the genetic improvement of common bean and to promote their consumption.

\section{ACKNOWLEDGEMENTS}

The authors are grateful for the financial support provided by CONACYT-Problemas Nacionales (project nr 2015-1-1119) and the Instituto Politécnico Nacional (project nrs 20170781 and 20170841).

\section{REFERENCES}

Akond, A.S.M., Khandaker, L., Bhertold, J., Gates, L., Peters, K., Delong, H., et al. 2011. Anthocyanins, total polyphenols and antioxidant activity of common bean. American Journal of Food Technology 6:385-394.

Aquino-Bolaños, E.N., García-Díaz, Y.D., Chávez-Servia, J.L., Carrillo-Rodríguez, J.C., Vera-Guzmán, A.M., and HerediaGarcía, E. 2016. Anthocyanins, polyphenols, flavonoids and antioxidant activity in common bean (Phaseolus vulgaris L.) landraces. Emirates Journal of Food and Agriculture 28:581-588.

Barampama,Z., and Simard, R.E. 1993. Nutrient composition, protein quality and antinutritional factors of some varieties of dry beans (Phaseolus vulgaris) grown in Burundi. Food Chemistry 47:159-167.

Bellato, S., Ciccoritti, R., Del Frate, V., Sgrulletta, D., and Carbone, K. 2013. Influence of genotype and environment on the content of 5-n alkylresorcinols, total phenols and on the antiradical activity of whole durum wheat grains. Journal of Cereal Science 57:162-169.

Bitocchi, E., Bellucci, E., Giardini, A., Rau, D., Rodriguez, M., Biagetti, E., et al. 2013. Molecular analysis of the parallel domestication of the common bean (Phaseolus vulgaris L.) in Mesoamerica and the Andes. New Phytologist 197:300-313.

Brand-Williams, W., Cuvelier, M., and Berset, C. 1995. Use of free radical method to evaluate antioxidant activity. LWT-Food Science and Technology 28:25-30.

Camacho, R., Ríos, M.C., Torres, I.,Acosta, J.A., Palomino,A.C., Ramos, M., et al. 2007. El consumo de frijol común (Phaseolus vulgaris L.) y su efecto sobre el cáncer de colon en ratas Sprague-Dawley. Agricultura Técnica en México 33:43-52.

Chavez-Santoscoy, R.A., Gutierrez-Uribe, J.A., Granados, O., Torre-Villalvazo, I., Serna-Saldivar, S.O., Torres, N., et al. 2014. Flavonoids and saponins extracted from black bean (Phaseolus vulgaris L.) seed coats modulate lipid metabolism and biliary cholesterol secretion in C57BL/6 mice. British Journal of Nutrition 112:886-899.

Chávez-Servia, J.L., Heredia-García, E., Mayek-Pérez, N., Aquino-Bolaños, E.N., Hernández-Delgado, S., Carrillo-Rodríguez, J.C., et al. 2016. Diversity of common bean (Phaseolus vulgaris L.) landraces and the nutritional value of their grains. p. 1-33. In Goyal, A.K. (ed.) Grain legumes. InTech, Rijeka, Croatia.

Chel-Guerrero, L., Domínguez-Magaña, M., Martínez-Ayala, A., Dávila-Ortiz, G., and Betancur-Ancona, D. 2012. Lima bean (Phaseolus lunatus) protein hydrolysates with ACE-I inhibitory activity. Food and Nutrition Sciences 3:511-521.

Chen, P.X., Tang, Y., Massimo, M.F., Pauls, P.K., Zhang, B., Liu, R., et al. 2015. Characterization of free, conjugated and bound phenolics and lipophilic antioxidants in regular- and non-darkening cranberry beans (Phaseolus vulgaris L.) Food Chemistry 185:298-308.

Dueñas, M., Hernández, T., and Estrella, I. 2006. Assessment of in vitro antioxidant capacity of the seed coat and the cotyledon of legumes in relation to their phenolic contents. Food Chemistry 98:95-103.

Espinosa-Alonso, L.G., Lygin, A., Widholm, J.M., Valverde, M.E., and Paredes-Lopez, O. 2006. Polyphenols in wild and weedy Mexican common beans (Phaseolus vulgaris L.) Journal of Agricultural and Food Chemistry 54:4436-4444. 
Ezeagu, I.E., and Ibegbu, M.D. 2010. Biochemical composition and nutritional potential of $u k p a$ : a variety of tropical lima beans (Phaseolus lunatus) from Nigeria - a short report. Polish Journal of Food and Nutrition Sciences 60(3):231-235.

FAOSTAT. 2015. Statistics of crops production 2014. Statistics Division, FAO, Rome, Italy. Available at http://faostat3 .fao.org/ download/Q/QC/E/ (accessed August 2017).

Florez, A., Pujolà, M., Valero, J., Centelles, E., Almirall, A., and Casañas, F. 2009. Genetic and environmental effects on chemical composition related to sensory traits in common beans (Phaseolus vulgaris L.) Food Chemistry 113:950-956.

García-Lafuente, A., Moro, C., Manchón, N., Gonzalo-Ruiz,A., Villares, A., Guillamón, E., et al. 2014. In vitro anti-inflammatory activity of phenolic rich extracts from white and red common beans. Food Chemistry 161:216-223.

Kan, L., Nie, S., Hu, J., Liu, Z., and Xie, M. 2016. Antioxidant activities and anthocyanins composition of seed coats from twenty-six kidney bean cultivar. Journal of Functional Foods 26:622-631.

Kishore, G., Ranjan, S., Pandey, A., and Gupta, S. 2010. Influence of altitudinal variation on the antioxidant potential of tartar buckwheat of wester Himalaya. Food Science and Biotechnology 19:1355-1363.

Lomas-Soria, C., Pérez-Ramírez, S.I., Caballero Pérez, J., Guevara-González, R.G., Guevara-Olvera, L., Loarca-Piña, G., et al. 2015. Cooked common beans (Phaseolus vulgaris L.) modulate renal genes in streptozotocin-induced diabetic rats. The Journal of Nutritional Biochemistry 26:761-768.

López, A., El-Naggar, T., Dueñas, M., Ortega, T., Estrella, I., Hernández, T., et al. 2013. Effect of cooking and germination on phenolic composition and biological properties of dark beans (Phaseolus vulgaris L.) Food Chemistry 138:547-555.

Manach, C., Augustin, S., Morand, C., Remesy, C., and Jimenez, L. 2004. Polyphenols: food sources and bioavailability. American Journal of Clinical Nutrition 79:727-747.

Marathe, S.A., Rajalakshmi, V., Jamdar, S.N., and Sharma, A. 2011. Comparative study on antioxidant activity of different varieties of commonly consumed legumes in India. Food and Chemical Toxicology 49:2005-2012.

McClean, P.E., Lee, R.K., Otto, C., Gepts, P., and Bassett, M.J. 2002. Molecular and phenotypic mapping of genes controlling seed coat pattern and color in common bean (Phaseolus vulgaris L.) The Journal of Heredity 93:148-152.

McGuire, R.G. 1992. Reporting of objective color measurements. HortScience 27:1254-1255.

Mojica, L., Meyer, A., Berhow, M.A., and Gonzalez-de-Mejia, E. 2015. Bean cultivars (Phaseolus vulgaris L.) have similar high antioxidant capacity, in vitro inhibition of $\alpha$-amylase and $\alpha$ glucosidase while diverse phenolic composition and concentration. Food Research International 69:38-48.

Moreno-Jiménez, M.R., Cervantes-Cardoza, V., Gallegos-Infante, J.A., González-Laredo, R.F., Estrella, I., García-Gasca, T.J., et al. 2014. Phenolic composition changes of processed common beans: their antioxidant and anti-inflammatory effects in intestinal cancer cells. Food Research International 76:79-85.

Muzquiz, M., Burbano, C., Ayet, G., Pedrosa, M.M., and Cuadrado, C. 1999. The investigation of antinutritional factors in Phaseolus vulgaris. Environmental and varietal differences. Biotechnologie, Agronomie, Société et Environnement 3:210-216.

Ombra, M.N., d'Acierno, A., Nazzaro, F., Riccardi, R., Spigno, P., Zaccardelli, M., et al. 2016. Phenolic composition and antioxidant and antiproliferative activities of the extracts of twelve common bean (Phaseolus vulgaris L.) endemic ecotypes of southern Italy before and after cooking. Oxidative Medicine and Cellular Longevity 2016(12):1-12. http://dx.doi. org/10.1155/2016/1398298.

Oomah, B.D., Cardador-Martínez, A., and Loarca-Piña, G. 2005. Phenolics and antioxidative activities in common beans (Phaseolus vulgaris L.) Journal of the Science of Food and Agriculture 85:935-942.

Oomah, B.D., Corbé, A., and Balasubramanian, P. 2010. Antioxidant anti-inflammatory activities of bean (Phaseolus vulgaris L.) hulls. Journal of Agricultural and Food Chemistry 58:8225-8230.

Possobom, M.T.D.F., Ribeiro, N.D., Zemolin, A.E.M., and Arns, F.D. 2015. Genetic control of the seed coat colour of Middle American and Andean bean seeds. Genetica 143:45-54.

Prolla, G.I.R., Barbosa, G.R., Veeck, L.A.P., Augusti, R.P., da Silva, P.L., Ribeiro, N.D., et al. 2010. Cultivar, harvest year, and storage conditions affecting nutritional quality of common beans (Phaseolus vulgaris L.) Ciência e Tecnologia de Alimentos 30:96-102.

Rocha-Guzmán, N.E., Herzog, A., González-Laredo, R.F., Ibarra-Peréz, F.J., Zambrano-Galván, G., and J. Gallegos-Infante, A. 2007. Antioxidant and antimutagenic activity of phenolic compounds in three different colour groups of common bean cultivars (Phaseolus vulgaris). Food Chemistry 103:521-527.

Romani, A., Vignolini, P., Galaredi, C., Mulinacci, N., Benedettelli, S., and Heimler, D. 2004. Germplasm characterization of Zolfino landraces (Phaseolus vulgaris L.) by flavonoid content. Journal of Agricultural and Food Chemistry 52:3838-3842.

Romano, A., Giosafatto, C.V.L., Masi, P., and Mariniello, L. 2015. Impact of dehulling on the physico-chemical properties and in vitro protein digestion of common beans (Phaseolus vulgaris L.) Food and Function 6:1345.

Romero-Arenas, O., Damián-Huato, M., Rivera-Tapia, J., Báez-Simón, A., Huerta-Lara, M., and Cabrera-Huerta, E. 2013. The nutritional value of beans (Phaseolus vulgaris L.) and its importance for feeding of rural communities in Puebla, Mexico. International Research Journal of Biological Sciences 2:59-65.

Sancho, R.A.S., Pavan, V., and Pastore, G.M. 2015. Effect of in vitro digestion on bioactive compounds and antioxidant activity of common bean seed coats. Food Research International 76:74-78. 
Singleton, V.L., and Rossi, J.A. 1965. Colorimetry of total phenolics with phosphomolybdic phosphotungstic acid reagents. American Journal of Enology and Viticulture 16:144-158.

Voysest, O. 2000. Mejoramiento genético del frijol (Phaseolus vulgaris L.): Legado de variedades de América Latina 19301999. Publicación CIAT Nr 321. Centro Internacional de Agricultura Tropical (CIAT), Cali, Colombia.

Wrolstad, R.E. 1976. Color and pigment analyses in fruit products. Station Bulletin 624. Agricultural Experimental Station of Oregon State University, Corvallis, Oregon, USA.

Xu, B.J., and Chang, S.K. 2012. Comparative study on antiproliferation properties and cellular antioxidant activities of commonly consumed food legumes against nine human cancer cell lines. Food Chemistry 134:1287-1296.

Xu, B.J., Yuan, S.H., and Chang, S.K.C. 2007. Comparative analyses of phenolic composition, antioxidant capacity, and color of cool season legumes and other selected food legumes. Journal of Food Science 72:S167-S177.

Zhang, X., Blair, M.W., and Wang, S. 2008. Genetic diversity of Chinese common bean (Phaseolus vulgaris L.) landraces assessed with simple sequence repeat markers. Theoretical and Applied Genetics 117:629-640.

Zhishen, J., Mengchengt, T., and Jianming, W. 1999. The determination of flavonoids contents in mulberry and their scavenging effects in superoxide radicals. Food Chemistry 64:555-559. 